\title{
Parental attitudes and approaches to biliteracy development and bilingualism
}

\author{
Muhammad Basri - Mark Garner - Mansur Akil
}

DOI: 10.18355/XL.2018.11.01.02

\begin{abstract}
The research explores the parental attitudes and approaches on Indonesian families to support their children L1 and L2 literacy practices and bilingualism in Australian home context. It employs a longitudinal ethnographic approach utilizing home indepth interview to collect data on the perception of the parents on biliteracy development and bilingualism and how they put into their home biliteracy and bilingualism practices; and the extent of the biliteracy approaches the parents apply in their home influence the responses of the children toward their biliteracy development and bilingualism. Research results demonstrate that more inspired and complex the parents were in the way to support the development of biliteracy and bilingualism at the Australian Indonesian families, and opening up space for engaging and learning biliteracy and bilingualism, better the instantaneous results of the biliteracy and bilingualism outcomes of the children were.
\end{abstract}

Key words: parental perception, literacy development, multilingualism

\section{Introduction}

Ayah, tidak ada PR, hanya baca buku ini saja

Dad, I don't have any homework, I'm just asked to read this book

Lukman, a boy from an Indonesian background, had just returned from playing with his friends and was upset at his father's telling him he should have completed his homework. His mother intervened, explaining to her husband how the Australian primary school differs from that in Indonesia. She said that in the former, by contrast with the latter, children are not required to do a large amount of homework in order to learn successfully either at home or at school.

This brief, relatively unremarkable scene seemed to encapsulate how Lukman was becoming more enculturated in his Australian environment, adopting the view that reading at home is a matter of choice. His changing attitude appeared to be central to developing his confidence and self-reliance in becoming literate in two languages. The scene also illustrates the roles his parents were playing in the process: the focus of the research reported in this paper.

\subsection{Aims, research questions and focus of the study}

The study, which was conducted over a one-year period, investigated the development of bilingualism, and in particular biliteracy, among children in Indonesian families living in Melbourne, Australia. The specific aim of the study was to explore the influence of parents on this development, by addressing the research question:

How do Indonesian parents' knowledge, attitudes, approaches, and behavior enhance their children's bilingualism and biliteracy in the Australian context?

The framework for the study was language ecology (see Baldauf, 2006; Haugen, 1972, 2003; Kaplan, Baldauf, 2008; Mühlhäusler, 2000). There has been an increasing number of ecological studies devoted to planning and policy in education for language diversity, maintenance, and development. Such policies (see, Hornberger, 2002, 2005b) are intended to provide a space for the use of as many 
languages as possible, in particular where one or more of these languages is endangered, in a given educational environment. Nonetheless, as Creese and Martin (2003) point out, there has been little research into the inter-connections between languages and their users in these contexts. The research reported here aimed to contribute to filling this gap by examining the ecology of developing biliteracy and bilingualism in the homes of Indonesian families living in Australia (referred to here as "Indonesian-Australian homes").

\section{The home literacy environment}

The experiences, attitudes, and materials pertaining to literacy that a child encounters and interacts with at home constitute the home literacy environment (Leseman, Jong, 1998; Payne, Whitehurst, \& Angell, 1994; Sénéchal et al., 1998; Whitehurst, Lonigan, 1998), which has been the focus of an increasing number of studies over the past three decades (e.g., Lonigan et al., 2000; Sénéchal, LeFevre, 2002; Whitehurst, Lonigan, 1998; Roberts, Jergens, Burchinal, 2005; Zentella, 2005). Studies into the home literacy environment (e.g. Barton, 1996; Roberts, Jergens, Burchinal, 2005; Duursma et al., 2007; Hood, Conlon, Andrews, 2008; Skibbe, Justice, Zucker, McGinty, 2008) have sought to increase our understanding of its place in the acquisition of children's literacy. A common finding is that children who acquire successful initial reading skills (Jiménez, García, and Pearson 1996) in the home literacy environment tend to remain good readers, while children who experience difficulty in learning to read tend to continue to have problems in reading throughout the school years (Baydar, Brooks-Gunn, \& Furstenberg, 1993; Cunningham, Stanovich, 1997).

In relation to adding to the findings of other studies undertaken in different cultural settings, the present study investigated the home literacy environment and parental practices dealing with the Indonesian-Australian context (cf. Bialystok, 1997; Saunders, 1988; Tagoilelagi-LeotaGlynn, McNaughton, MacDonald, Farry, 2005). Literacy is highly valued in the Indonesian middle-class: parents expect their children to achieve high standards, particularly in language-related subjects. Their children are encouraged to work hard at school and to do a large amount of homework exercises and drills from textbooks. The direct part the parents play in their achievement, however, may be limited by the amount of time they can devote to working with the children. The role of the parental attitudes in the home literacy environment is crucial for the children biliteracy development as most of the Indonesian children depend on their parents' home instruction.

\section{The study}

The study utilized a qualitative (LeCompte and Schensul, 1999; 2010), longitudinal ethnographic approach (Lillis, 2008; Erickson, 1996; Florio-Ruane, McVee, 2002; Gee, 1989; Heath, 1982, 1983). Ethnography (Heath 1982) enables the researcher to explore the insights of traditional anthropological naturalistic research in a cross-cultural context. A longitudinal study (see Christensen, 2004) enables the researcher to trace development (in the present case, the development of biliteracy and bilingualism) over one year.

The research concentrated mainly on the changes in parents' perceptions of biliteracy and bilingualism and their influence on their practices at home. Primary data were gathered from detailed interviews, and literacy materials used (and sometimes created) by children and their parents. It was also necessary to assess the primary data against the background of the local institutional, national, and global contexts. To this end, secondary, documentary sources were consulted, including statements of policy, procedural guidelines, and school newsletters. 
The study sample comprised four Indonesian-Australian homes. The parents' ages ranged from 35 to 47 . One of the families had acquired permanent resident status in Australia over the past 2-3 years. In the other three homes, the mothers were international students at a nearby university. The Indonesian government provides considerable funding to enable female academics and other professionals to obtain a higher degree in an overseas university, in order to improve the gender balance in the professions. The fathers in these homes, who were officially dependents of their wives, were thus experiencing a reversal of roles and were expected to take the major responsibility for the housework and to look after the children, including taking them to and from school every day and participating in some school-based and extracurricular activities. The men were legally permitted to engage in some paid casual employment and were thereby able to supplement the household income by buying school uniforms and books and funding leisure pursuits. In one of the families, however, the father was frequently absent, as he continued to work for his employers in Indonesia.

The children in the study, whose ages ranged from 5 to 11 years old, were currently studying in Australian primary schools and were consequently becoming bilingual (see Kenner, Gregory, Larson, Marsh, 2012).

Within three families that were listed as international students (Arini/ Arman, Nurmin/ Suroto, and Andriani/ Anggoro), the fathers were being considered as the students' dependants and capable of working in Australia basis.

The families (Warda/ Emil) who were permanent resident had parents had employment in Melbourne and had limited time to interact with their children (Haris, Hasyim, and Halim). Whereas Haris and his brother and mother had only been staying for the past year in Australia, they had in fact resided in Australia before commencing their school in Indonesia. Emil had, on the other hand, rapidly returned to Melbourne taking up permanent residence, and his wife and his sons joined him after two years in Australia.

\subsection{Data analysis}

Data on perspectives from the parents and their home biliteracy practices was collected through in-depth interview. Data were analyzed for two key themes in relation to the research question. The first theme focussed on the parents' attitudes towards biliteracy and bilingualism, and the second one focused on their practices and behavior in the home with respect to their development.

Following Patton (1987), the analysis of the ethnographic data consisted of three overlapping stages. The first was data reduction and summary; the second, identification of themes and patterns; and the third, making links to findings in the relevant published literature (LeCompte and Schensul, 1999).

\section{Results and discussion}

\subsection{Parental attitude on biliteracy development and bilingualism}

The characteristics of the various parental approaches to language use and literacy in their Australian homes were evidently related to their beliefs about the role of language in communication, about the ways in which literacy is acquired, and about the interaction between the two languages in the bilingual context. The parents in all families in the study expressed a high level of commitment to their children's English learning. They differed, however, in their attitudes towards maintaining and advancing competence in the two languages and towards their own role in supporting the development of biliteracy.

An important construct in interpreting the data is that of the family as either Child-Focused Family (CFF) or Parent-Directed Family (PDF). A CFF focuses on each child's well-being and responds to the individual's persona. The PDF has explicit expectations with regard to achieving biliteracy and bilingualism and expects 
the children to engage in specific behaviors to realize these expectations (cf. Figueroa, Suh, \& Byrnes, 2015)

\subsubsection{Child-focused families}

CFFs demonstrated largely child-centered approach towards language use in general, and literacy particular, at home (see Richards, 2006). It is an implicitly constructivist view (see Vygotsky, 1978, 2012), in which learning is seen as autonomous and discovery-driven. It was manifested in the data in many ways, discussed below; in broad summary, the parents adapt their communication (including the use of both L1 and L2) and their practices in relation to the children's literacy in order to negotiate meaning, ensure comprehensibility, and encourage their children to enjoy reading and writing. For example, the family 1 (Arini/ Arman) said that 'we let our daughter (Nanda) read any books that she likes best. However, we just check later how well she understands the book. The most important thing for Nanda is to enjoy her reading and writing both in L1 and L2 as well as communicating the two languages interchangeably'.

In the families classified as CFF, the parents were focussed on each child's well-being and responded to the individual's persona. The parents indicated at least an implicit awareness of how language functions in spoken and written communication (Kirkpatrick, 2007). For example, the family of Nurmin/ Suroto (Family 2) explained what they did to their sons, Fasya and Lukman, in weekend activities as they said: 'we always ask our sons what they need in the activities on Saturday and Sunday to make them feeling comfortable staying in Melbourne.'.

In the CFFs, the parents shortened or simplified their communication when talking to their children about their reading and writing. They treated the children as equal partners in acquiring literacy (Gynne and Bagga-Gupta, 2013) and encouraged their children initiatives in language learning. They placed a high value on mutual understanding in interactions between the father and the mother with respect to the children's development in both languages (May 2011). For example, the family 1 ( Arini/Arman) discussed with their daughter, Nanda, about the use of Indonesian language in the school, and Nanda explained to her parents: 'I like the way my classroom teacher greeted me Selamat pagi, Apa kabar? [Good morning, how are you?]

In this way, in the CFFs provided, even when the issue was not discussed explicitly, a rich environment was created for biliteracy and bilingualism within the home.

\subsubsection{Parent-directed families}

The parents in the PDFs were actively involved in their children's language development. They sought to encourage the children to adopt certain attitudes towards the L1 and L2. They had explicit expectations with regard to achieving biliteracy and bilingualism and expected the children to engage in specific behaviors to realize these expectations (cf. Figueroa, Suh, Byrnes, 2015). There were both similarities and differences between the two families, and between the parents within each family, in the ways in which they went about trying to achieve their ends.

One area of contrast arose from the language that was focussed on in the home (Lee \& Anderson, 2009). The family of Warda/ Emil were very much concerned with the maintenance of Indonesian language and culture. For example, Warda/Emil (Family 3) as the parent of Haris predominantly use Indonesian to communicate with their sons at home, to read the Qur'an, and to sing Islamic songs.

The family 4 (Andriani/ Anggoro), by contrast, concentrated on the children's development in English. The mother insisted on the use of English between herself and the daughters, and between the two girls. She appeared to believe that this would

XLinguae, Volume 11 Issue 1, January 2018, ISSN 1337-8384, eISSN 2453-711X 
be beneficial both for the children's competence in English and also for her own. The daughters thus had very limited opportunities to use their L1. When her father returned for a brief period from his work in Jakarta, Indonesian became the predominant medium of communication; the mother expressed her unease at this, as she felt that her own English (and perhaps her daughters') was deteriorating. She thought that Indonesian did not matter with her daughters since they would return to Jakarta where Indonesian as the main language used in the society.

During the father's stay in Melbourne, Mother Andriani tried to establish a dual approach, in which he would use the L1, and she would use the L2. This one parent - one language approach has been shown to be successful in certain families in fostering biliteracy and bilingualism (Döpke, 1992; Basri, Patak, 2015). For example, the family 4 (Andriani/ Anggoro) treated Wendy, their daughter, differently in the home literacy practices. Wendy, on the one hand, interacted with her father on her reading and writing activities using Indonesian such as reading the Qur'an in the afternoon or evening, writing up a story from Indonesia. On the other hand, Wendy's mother, Andriani, communicated strictly with her in English in all activities at home such as reading the book from school, writing up a daily life experience to bring to school. As a result, Wendy's performance in reading and writing both in L1 and L2 markedly developed over one year of schooling.

\subsection{Parental approaches to support biliteracy development and bilingualism of their children in Australian home context}

\subsubsection{Parents in child-focused family}

The parents' features in the CFF were the diverse parts of the family in home literacy practice. In supporting the children's home literacy practices, the fathers who accompanied their wives (using a dependent's visa to stay in Australia) appeared to assist their wives in home activities that would normally be conducted by the mothers in their roles as housewives. The reason for this appeared to be that they believed their wives were more knowledgeable on education, in particular in Australian schools. For example, a home conversation between Suroto and Nurmin (Family 1) as husband and wife as follows: "Kalau urusan sekolahnya Fasya dan Lukman, nanti Mami yang urus karena engkau yang mengerti tentang sekolahan di Australia" (For the school business on Fasya and Lukman, will you look after our sons since you understand the Australian educational system). This indicated that the parents were more flexible than would conventionally be the circumstance for parents in Indonesia: they allowed their children to adjust to the present situation in school and home (Haneda, 2006; McCarthey, 1997; Gaus-Sultan-Basri, 2017). The mothers exhibited their childcentered approach in managing the activities of literacy with changing various natures of activities. On the other hand, both families at the beginning of their time in Australia appeared to be more parent-centered, directing their children in their home biliteracy learning. For instance, I was in their home observing the father of Fasya and Lukman telling his sons to complete their homework after coming back from school. They stayed in a house with three bedrooms located nearby university. They lived with other masters students from Indonesia studying at the same university. Coming back from school, Fasya and Lukman were urged by their father: "complete your homework first then play." This approach was originally from Indonesia where students have many assignments every day; parents were supposed to ensure that their children complete their homework precisely based on the textbook as the only resource for literacy learning in the school. The father was shocked hearing response from Lukman: "Dad, no homework here, I just have to read a book tonight."

The father of Lukman and Fasya was shocked since he had never experienced hearing the response, which was unfamiliar to Indonesian children arguing their parents. This father protested to his wife stating: 


\begin{tabular}{|l|l|}
\hline "Ma, lihat itu Lukman. Dia tidak & Mom, look at Lukman. He does not care \\
lagi mau mendengar, disuruh kerja & anymore when asking him to complete his \\
PR, eh ngambek. Ada apa dengan & homework, he complained. What was \\
Lukman?" & wrong with him? \\
\hline
\end{tabular}

Lukman's mother, who knows the Australian educational system from her experience studying education at the Australian university, came up to her husband making him feeling relaxed with the present circumstances and tell him as follows:

\begin{tabular}{|l|l|}
\hline "Mas, pekerjaan rumah di Australia & "Darling, homework here in Australia is \\
tidak sama dengan di Indonesia yang \\
different from Indonesia where children \\
hampir tidak ada istrahatnya", Di \\
sini, anak-anak senang pergi of homework without any rest. \\
sekolah"
\end{tabular}

These specific examples are interesting cross-culturally as the fathers tell the children how to do their homework as they usually do in Indonesia. Rather, giving children's experience with different cultural ways in working through media and the school, did not have the preferred impact in relation to the children biliteracy development. At this time, the families considered the home became a place of pressure in learning literacy, particularly in connection with homework including official literacy work, even though the fathers steadily became more tolerant of the diverse setting, and their approach is more child-centered in biliteracy learning.

These two families' mothers performed in a different way from their husbands. With their children, they were open-minded and tolerant in the way their children learn to deal with learning in Australian situation, positioning children as the center of learning literacy. The mother of Nanda, for instance, always carefully listened to her daughter narrating her school activities. She often asked Nanda in the family room to show her home reading activities, asking Nanda "Nanda, what have you read?" She replied:

"While showing a novel, I have read this entire book. At that point she narrated in Indonesian: ini buku tentang pertunjukan orang tua lalu terjadi masalah karena orang tuanya terlibat tanda tangan palsu". (This book is about the parent who got problem because of his fake signature).

\subsubsection{Parents PDFs}

In these families, the approach to literacy practices was parent-centred (Zentella, 2005) terms 'situation-centered'). They monitored and controlled the literacy practices at home extensively. Warda, for example, whose main role was caring her three sons, frequently approached her sons when they were doing something on the two computers in their learning room. She encouraged her sons saying: "kamu kerjakan PR nak, itu bagus" (It is good to do your homework, son). By contrast, the father regularly checked what they had learned in school. His sons discussed topics he suggested. His son, Haris, expressed his school project on Indonesia and told his father, "I could explore about the issues on culture, population, and the product." His father responded, "How?" "I would use the internet to search for that information." The father was trying to encourage his son to express his learning activities as an approach to stimulating discussion and interaction at the child's level. His father viewed his main role as preparing his son to engage in home literacy practices.

In the family of Haris, the home literacy practices were facilitated with technology. Haris' home, for example, had access to direct TV programs (see PurcellGates, 1996) from Indonesia such as Rajawali Citra Televisi Indonesia (RCTI), Televisi Pendidikan Indonesia (TPI), Televisi Republik Indonesia (TVRI), and 
Surabaya Citra Televisi (SCTV). Consequently, Haris, as well as his brothers, were immersed in their L1 through programs presented on all TV stations. For instance, RCTI displayed cartoons for children, TPI presented programs for education containing quizzes and programs for schools, TVRI exhibited late news and up-todate affairs, and SCTV exposed specific documentaries on unique news and events in Indonesia. Haris, for instance, stated: "I am glad to watch cartoon films on RCTI every evening." This, however, contributed little to literacy, modeling and literacy use equally promoted in the sorts of TV shows or home literacy programs, like a discussion about thoughts in reading a text.

Activities for home literacy, like writing and reading, were valued highly within this family where children are having flexible playing nearby home, however, with obvious prescriptions and limits. For instance, the mother of Haris said:

\begin{tabular}{|l|l|}
\hline Anak-anak boleh main dalam rumah & Children may play in the house as long as \\
asalkan terkait dengan pelajaran & it relates to school subjects, may play on \\
sekolah, boleh main computer dan & the computer and browse the Internet to do \\
browsing di internet untuk kerjakan & homework. They may play games \\
PR, boleh juga main game sesekali & occasionally in order not to get bored at \\
supaya tidak bosan di rumah. & home. Computers are also used to search \\
Komputer juga digunakan untuk & for Japanese songs to learn Japanese until \\
mencari lagu Jepang untuk belaja & the children were creative in their \\
bahasa Jepang, sampai anak-anak & biliteracy learning. \\
bigitu kreatif. & \\
\hline
\end{tabular}

The mother of Haris contended that children were free to work on the computers for their literacy homework. Snyder, Angus, Sutherland-Smith, (2002), however, argue that accessing computers at home is insufficient for children and their families to develop literacy. They conclude that the old inequalities access have not disappeared, but are playing out in new ways in the context of the networked society. She highly valued the creativity of her children using the available resources at home for learning biliteracy and bilingualism. She had a strong concentration on home literacy, and placed a high value on school literacy learning, rather than regarding such enjoyable activities as legitimate in their own right, independently of what could be learned from them.

The other feature characterizing the family of Haris was both mother and father consistently used Indonesian at home when communicating with the three children. Although the children talked almost entirely in English, the parents constantly replied in Indonesian. This family communication was intentionally set by these parents to sustain their children's L1.

\section{Conclusion}

The four Indonesian families demonstrated a number of marked differences in their attitudes and approaches to the development of biliteracy and bilingualism at home. These marked differences appeared not to arise from their experience of living in Australia, or from the parents' educational level.

Both parents in the two PDFs had a high level of education. These families appeared to have chosen to be directive in their approach to developing their children's literacy practices. For the family of Haris, family and home were seen as the center for the transmission and maintenance of the first language and culture, which were the focus of literacy practices (Hornberger, 2005; Purcell-Gates, 1996). Emphasis was placed, for example, on inculcating religion-based values and practices (Poveda, Cano, Palomares-Valera, 2005); providing information and developing an understanding of events taking place in Indonesia; and practicing traditional Indonesian family roles. Because of the family's status as permanent residents in 
Australia, all such linguistic and cultural education had to occur within the home domain.

The approach in Wendy's family, in particular, that of the mother, Andriani, manifested a desire to inculcate non-traditional, Western values. Contrary to research findings in other L2 environments, in which mothers have been found to promote the maintenance of L1 (e.g., Weigel, Martin, Bennett, 2006), in this instance Andriani typically interacted with the children in English, encouraged L2 literacy practices, and promoted views of the equality and rights of women. This means that she felt biliteracy and bilingualism would take care of themselves.

As in the PDFs, both sets of parents in the CCFs were well educated; however, unlike the parents in the former, they placed equal value on L1 and L2 in the home. These parents appeared to be guided by the personalities and interests of each child in literacy and language choice, encouraging both L1 and L2 home literacy practices (Curry, Lillis, 2004).They demonstrated a relaxed to their children's using L1 and L2 interchangeably, they were flexible in their parental roles, responding according to the requirements of the child in any given situation rather than according to those of a traditional Indonesian family. Both L1 and L2 used in interactions and literacy practices, following the needs and preferences as verbalized by the child. They took the opportunity to further the children's appreciation of biliteracy and bilingualism by encouraging activities in either language or both. Their homes were domains for translanguaging (see Hornberger, Link, 2012) in interactional texts while utilizing the appropriate level of language to enable the parents to check the child's comprehension and engagement with the issues at hand.

Both approaches, those of the PDFs and of the CCFs, appeared to be effective in realizing the goals the parents desired for their children. The evidence was that, regardless of family type, the more focused the parents were in supporting the development of biliteracy and bilingualism in the Australian context by providing opportunities for learning and engagement at home, the more successful were the outcomes. The most successful family in this respect was the family 1 in which the parents evinced strong empathy with the needs of their children in the present educational context. Their support for developing L1 and L2 literacy at home, incorporating TV and internet use, provided a supportive environment for such development. Nonetheless, the fact that both Lukman and Fasya, from contrasting family types, demonstrated significant advances in biliteracy and bilingualism was evidence that their families were successful in fostering biliteracy and bilingualism practices (Hornberger, 2002, 2005b), with positive educational consequences.

The findings of this research suggest that the study of biliteracy and bilingualism development of the primary school children in an L2 context needs to go beyond a focus on single factors, such as family type or language attitudes, by integrating multiple factors within an ecological framework. In this way, it will become possible to address in a more sophisticated manner one aspect of the challenge of nurturing and preserving language diversity. The present study of Indonesian families in Australia found that children can become biliterate in linguistically aware families in which both languages are highly valued in the home, and the domestic environment and specific literacy practices are supportive to learning.

The ecological approach was pioneered by Haugen (1971) in his study of language attitudes among bilingual communities, which he described according to the parameters of status and intimacy (Bernstein, Solomon, 1999) as related to personal identity. Using this broad framework, the present study has shown that the influence of language attitudes on the development of bilingualism in an L2 setting is complex: contrasting attitudes and family types can lead to similar language development. For instance, the parents in Family 1 justified their commitment to using the L1

XLinguae, Volume 11 Issue 1, January 2018, ISSN 1337-8384, eISSN 2453-711X 
(Indonesian) on the grounds that the family would return to Indonesia and the children would require a high level of competence in the L1. By contrast, parents in Family 3, Australian permanent residents, manifested a different motivation. They had a keen interest in the children's educational development and a strong desire to enhance family intimacy through their everyday domestic communication, rather than adhering to the traditional values associated with L1. Examining the interaction of contrasting attitudes, family types, and approaches to the development of biliteracy illustrates the value of the ecological framework to achieving an understanding of the complex factors influencing biliteracy and bilingualism in minority languages.

It would be an illuminating step to conduct further research into the sample of the present study. What will be the linguistic and educational consequences for the five children who are to return to their home country, Indonesia, where the status of the L1 and L2 is very different? What will they be for the others, who remain in Melbourne and become more established in Australian society? To what extent will contrasting parental attitudes and approaches to biliteracy development and bilingualism identified in the study reported here influence future language competence in the two languages. For instance, in the case of Family 4, how will the parents' one parent-one language approach maintain and develop her biliteracy development and bilingualism when Wendy is back home in Indonesia? To what extent will her experiences and learning outcomes in the very different school system be similar or dissimilar to those of the children who remain in Australia? Such a longitudinal study would provide significant insights into the ecology of the development of biliteracy and bilingualism.

\section{Bibliographic references}

BALDAUF JR, R. B. 2006. "Rearticulating the case for micro language planning in a language ecology context," Curr. Issues Lang. Plan., vol. 7, no. 2-3, pp. 147-170. ISSN 1466-4208.

BARTON, D. 1996. "Family literacy programmes and home literacy practices," DAC Bak. J.; Fox, C.(Ed.), Challenging ways knowing English, maths Sci., pp. 52-61. ISBN 9780750705257.

BASRI, M. - PATAK, A.A. 2015. Exploring Indonesian students' perception of Mendeley Reference Management Software in academic writing. In Information Technology, Computer, and Electrical Engineering (ICITACEE), 2015 2nd International Conference on. IEEE, pp. 8-13. ISBN 9781479998616.

BAYDAR, N. - BROOKS-GUNN, J. - FURSTENBERG, F. F. 1993. "Early warning signs of functional illiteracy: Predictors in childhood and adolescence," Child Dev., vol. 64, no. 3, pp. 815 - 829. ISSN 1467-8624.

BERNSTEIN, B. - SOLOMON, J. 1999. "'Pedagogy, Identity and the Construction of a Theory of Symbolic Control': Basil Bernstein questioned by Joseph Solomon," Br. J. Sociol. Educ., vol. 20, no. 2, pp. 265-279. ISSN 0142-5692.

BIALYSTOK, E. 1997. "Effects of bilingualism and biliteracy on children's emerging concepts of print.," Dev. Psychol., vol. 33, no. 3, p. 429. ISSN 1939-0599.

CREESE, A. - MARTIN, P. 2003. "Multilingual classroom ecologies: Interrelationships, interactions and ideologies," Int. J. Biling. Educ. Biling., vol. 6, no. 3-4, pp. 161-167. ISSN 1367-0050.

CUNNINGHAM, A. E. - STANOVICH, K. E. 1997. "Early reading acquisition and its relation to reading experience and ability 10 years later.," Dev. Psychol., vol. 33, no. 6, p. 934. ISSN 1939-0599.

CURRY, M. J. - LILLIS, T. 2004. "Multilingual scholars and the imperative to publish in English: Negotiating interests, demands, and rewards," TESOL Q., vol. 38, no. 4, pp. 663-688. ISSN 1545-7249. 
DOPKE, S. 1992.One parent one language: An interactional approach, vol. 3. John Benjamins Publishing. ISBN 9027286671.

DUURSMA, E. - ROMERO-CONTRERAS, S. - SZUBER, A. - PROCTOR, P. SNOW, C. - AUGUST, D. - CALDERON, M. 2007. The role of home literacy and language environment on bilinguals' English and Spanish vocabulary development. Appl. Psycholinguist., vol. 28, no. 01, pp. 171-190. ISSN 1469-1817.

ERICKSON, F. 1996. "On the evolution of qualitative approaches in educational research: From Adam's task to Eve's," Aust. Educ. Res., vol. 23, no. 2, pp. 1-15. ISSN 0311-6999.

FIGUEROA, A. M. - SUH, S. - BYRNES, M. 2015. Co-constructing beliefs about parental involvement: Rehearsals and reflections in a family literacy program. Linguist. Educ., vol. 31, pp. 44-58. ISSN 0898-5898.

FLORIO-RUANE, S. - MCVEE, M. 2002. "Ethnographic approaches to literacy research," Methods Lit. Res. Methodol. chapters from Handb. Read. Res., vol. 3, pp. 77-86. ISBN 9781135649623.

GAUS, N. - SULTAN, S. - BASRI, M. 2017. State Bureaucracy in Indonesia and its Reforms: An Overview. International Journal of Public Administration, 40(8), pp.658-669. ISSN 0190-0692.

GEE, J. P. 1989. “What Is Literacy?.," J. Educ., vol. 171, no. 1, pp. 18-25. ISBN 9780805829983.

GYNNE, A. - BAGGA-GUPTA, S. 2013. "Young people's languaging and social positioning. Chaining in 'bilingual' educational settings in Sweden," Linguist. Educ., vol. 24, no. 4, pp. 479-496. ISSN 08985898.

HANEDA, M. 2006. "Becoming literate in a second language: Connecting home, community, and school literacy practices," Theory Pract., vol. 45, no. 4, pp. 337-345.. ISSN 0040-5841.

Haugen, E.I., 1972. The Ecology of Language. Stanford University Press. ISBN 9780804708029.

HAUGEN, E., 2003. The Ecology of Language. In A. Gerbig, ed. Gerbig, A. (ed)The ecolinguistics reader: Language, ecology and environment. Taylor \& Francis, pp. 5766. ISBN 1466-4208.

HEATH, S. B. 1983. Ways with words: Language, life and work in communities and classrooms. Cambridge University Press. ISBN 0521273196.

HEATH, S. B. 1982. Ethnography in Education: Defining the Essentials.

HOOD, M. - CONLON, E. - ANDREWS, G. 2008. "Preschool home literacy practices and children's literacy development: A longitudinal analysis.," J. Educ. Psychol., vol. 100, no. 2, p. 252. ISSN 1939-2176.

HORNBERGER, N. H. 2002. "Multilingual language policies and the continua of biliteracy: An ecological approach," Lang. Policy, vol. 1, no. 1, pp. 27-51. ISSN 1568-4555.

HORNBERGER, N. H. 2005. "Heritage/community language education: US and Australian perspectives," Int. J. Biling. Educ. Biling., vol. 8, no. 2-3, pp. 101-108. ISSN 1367-0050.

HORNBERGER, N. H. 2005. "Opening and filling up implementational and ideological spaces in heritage language education,” Mod. Lang. J., pp. 605-609. ISSN 0026-7902.

HORNBERGER, N. H. - LINK, H. 2012. "Translanguaging and transnational literacies in multilingual classrooms: A biliteracy lens," Int. J. Biling. Educ. Biling., vol. 15, no. 3, pp. 261-278. ISSN 1367-0050.

JIMENEZ, R. T. - GARCIA, G. E. - PEARSON, P. D. 1996. "The reading strategies of bilingual Latina/o students who are successful English readers: Opportunities and obstacles," Read. Res. Q., vol. 31, no. 1, pp. 90-112. ISSN 1936-2722.

XLinguae, Volume 11 Issue 1, January 2018, ISSN 1337-8384, eISSN 2453-711X 
KAPLAN, R. B. - BALDAUF, R. B. 2008. "An ecology perspective on language planning," in Encyclopedia of language and education, Springer, pp. 2937-2948. ISBN 0387328750.

KENNER, C. - GREGORY, E. - LARSON, J. - MARSH, J. 2012. "Becoming biliterate," SAGE Handb. early Child. Lit., pp. 364-378.

KIRKPATRICK, A. 2007. "Setting attainable and appropriate English language targets in multilingual settings: A case for Hong Kong,” Int. J. Appl. Linguist., vol. 17, no. 3, pp. 376-391. ISSN 08026106.

LECOMPTE, M. D. - SCHENSUL, J. J.. 1999.Analyzing and interpreting ethnographic data. Rowman Altamira. ISBN 0761989749.

LECOMPTE, M. D. - SCHENSUL, J. J.. 2010.Designing and conducting ethnographic research, vol. 1. Rowman Altamira. ISBN 0759118698.

LEE, J. S. - ANDERSON, K. T. 2009. "Negotiating linguistic and cultural identities: Theorizing and constructing opportunities and risks in education," Rev. Res. Educ., vol. 33, no. 1, pp. 181-211. ISSN 0091-732X.

LESEMAN, P. P. M. - JONG, P. F. 1998. "Home literacy: Opportunity, instruction, cooperation and social - emotional quality predicting early reading achievement," Read. Res. Q., vol. 33, no. 3, pp. 294 - 318. ISSN 1936-2722.

LILLIS, T. 2008. "Ethnography as method, methodology, and 'Deep Theorizing' closing the gap between text and context in academic writing research," Writ. Commun., vol. 25, no. 3, pp. 353-388. 0741-0883.

LONIGAN, C. J. - BURGESS, S. R. - ANTHONY, J. L. 2000. "Development of emergent literacy and early reading skills in preschool children: evidence from a latent-variable longitudinal study.," Dev. Psychol., vol. 36, no. 5, p. 596. ISSN 19390599 .

MAY, S. 2011. "The disciplinary constraints of SLA and TESOL: Additive bilingualism and second language acquisition, teaching and learning," Linguist. Educ., vol. 22, no. 3, pp. 233-247. ISSN 08985898.

MCCARTHEY, S. J. 1997. "Connecting home and school literacy practices in classrooms with diverse populations," J. Lit. Res., vol. 29, no. 2, pp. 145-182. ISSN 1086-296X.

MÜHLHÄUSLER, P. 2000. "Language planning and language ecology," Curr. Issues Lang. Plan., vol. 1, no. 3, pp. 306-367. ISSN 1466-4208.

PATTON, M. Q. 1987.How to use qualitative methods in evaluation, no. 4. Sage. ISBN 0803931298.

PAYNE, A. C. - WHITEHURST, G. J. - ANGELL, A. L. 1994. "The role of home literacy environment in the development of language ability in preschool children from low-income families," Early Child. Res. Q., vol. 9, no. 3, pp. 427-440. ISSN 0885-200.

POVEDA, D. - CANO, A. - PALOMARES-VALERA, M. 2005. "Religious genres, entextualization and literacy in Gitano children," Lang. Soc., vol. 34, no. 01. ISSN 0047-4045.

PURCELL-GATES, V. 1996. "Stories, Coupons, and the“ TV Guide:' Relationships between Home Literacy Experiences and Emergent Literacy Knowledge," Read. Res. Q., pp. 406-428. ISSN 0034-0553.

RICHARDS, J. C. 2006.Communicative Language Teaching Today. Cambridge University Press. ISBN 9780521934367.

ROBERTS, J. - JERGENS, J. - BURCHINAL, M. 2005. "The role of home literacy practices in preschool children's language and emergent literacy skills," J. Speech, Lang. Hear. Res., vol. 48, no. 2, pp. 345-359. ISSN 1092-4388.

SAUNDERS, G. 1988.Bilingual Children: From Birth to Teens. ERIC. ISBN 1853590096. 
SÉNÉCHAL, M. - LEFEVRE, J. 2002. "Parental involvement in the development of children' s reading skill: A five - year longitudinal study," Child Dev., vol. 73, no. 2, pp. 445 - 460. ISSN 1467-8624.

SENECHAL, M. - LEFEVRE, J. - THOMAS, E. M. - DALEY, K. E. 1998. "Differential effects of home literacy experiences on the development of oral and written language,” Read. Res. Q., vol. 33, no. 1, pp. 96-116. ISSN 1936-2722.

SKIBBE, L. E. - JUSTICE, L. M. - ZUCKER, T. A. - MCGINTY, A. S. 2008. "Relations among maternal literacy beliefs, home literacy practices, and the emergent literacy skills of preschoolers with specific language impairment," Early Educ. Dev., vol. 19, no. 1, pp. 68-88. ISSN 1040-9289.

SNYDER, I. - ANGUS, L. - SUTHERLAND-SMITH, W. 2002. "Building equitable literate futures: Home and school computer-mediated literacy practices and disadvantage," Cambridge J. Educ., vol. 32, no. 3, pp. 367-383. ISSN 0305-764X.

TAGOILELAGI-LEOTAGLYNN, F. - MCNAUGHTON, S. - MACDONALD, S. FARRY, S. 2005. "Bilingual and biliteracy development over the transition to school,” Int. J. Biling. Educ. Biling., vol. 8, no. 5, pp. 455-479. ISSN 1367-0050.

VYGOTSKY, L. S. 1978. Mind in Society: the development of higher psychological process. Harvard University Press. ISBN 0674576284.

VYGOTSKY, L. S. 2012.Thought and language. MIT Press. ISBN 026251771X.

WEIGEL, D. J. - MARTIN, S. S. - BENNETT, K. K.. 2006. "Mothers' literacy beliefs: Connections with the home literacy environment and pre-school children's literacy development," J. Early Child. Lit., vol. 6, no. 2, pp. 191-211. ISSN 14687984.

WHITEHURST, G. J. - LONIGAN, C. J. 1998. "Child development and emergent literacy," Child Dev., vol. 69, no. 3, pp. 848-872. ISSN 1467-8624.

ZENTELLA, A. C. 2005. "Premises, promises, and pitfalls of language socialization research in Latino families and communities," Build. strength Lang. Lit. Lat. Fam. communities, pp. 13-30.

Words: 6493

Characters: 42702 (23,72 standard page)

Prof. Drs., MA., Ph.D. Muhammad Basri

Department of English

Universitas Negeri Makassar

Jalan A.P. Pettarani, Makassar

Indonesia

muhammadbasri@unm.ac.id

Rev. Dr. Mark Garner

Department of Media, Culture and Language

University of Roehampton

046 Parkstead House, Whitelands, London

The United Kingdom

mark.garner@roehampton.ac.uk

Prof. Dr. Mansur Akil

Department of English

Universitas Negeri Makassar

Jalan A.P. Pettarani, Makassar

Indonesia

mansur.akil@unm.ac.id

XLinguae, Volume 11 Issue 1, January 2018, ISSN 1337-8384, eISSN 2453-711X 